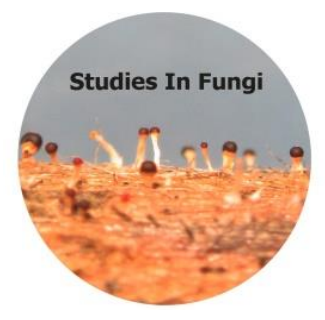

Studies in Fungi 3(1): 39-48 (2018) www.studiesinfungi.org

ISSN 2465-4973

\title{
Article
}

Doi 10.5943/sif/ 3/1/6

Copyright $\odot$ Institute of Animal Science, Chinese Academy of Agricultural Sciences

\section{Review of the lichen genus Usnea in the Philippines}

\author{
Galinato MGM ${ }^{1 *}$, Baguinon $\mathrm{JRC}^{1}$ and Santiago KAA ${ }^{2}$ \\ ${ }^{1}$ The Graduate School, University of Santo Tomas, España 1008 Manila, Philippines \\ ${ }^{2}$ Monash University Malaysia, Jalan Lagoon Selatan, 47500 Bandar Sunway Selangor Darul Ehsan, Malaysia
}

Galinato MGM, Baguinon JRC, Santiago KAA 2018 - Review of the lichen genus Usnea in the Philippines. Studies in Fungi 3(1), 39-48, Doi 10.5943/sif/3/1/6

\begin{abstract}
The fruticose lichen Usnea is a cosmopolitan genus also found in the mountains of the Philippines. Despite its abundance, though, this lichen genus is not extensively studied in the country. Since the Philippine Usnea holds great potential in pharmaceutical and agricultural research, the basic knowledge on this lichen is important to establish. Therefore, this paper takes a detailed review of Usnea in the Philippines and summarizes all the literatures that have been conducted on it in all aspects. Further, the provinces that were already reported of the occurrence of this genus are plotted in one figure to also highlight those that have not been explored yet. Currently, 81 species of Usnea were reported in the country. This includes a species that was previously under the genus Usnea but has been arguably reclassified to a different genus in the present (i.e., Eumitria). This review also hopes to direct future studies regarding Usnea.
\end{abstract}

Key words - biodiversity - checklist - distribution - fungal taxonomy - fruticose

\section{Introduction}

The lichen genus Usnea Dill. ex Adans. is one of the most widespread fruticose lichen genera in the world. Within this genus are $~ 600$ species (Hawksworth et al. 1995) which are all distinguished by their beard-like morphology (Randlane et al. 2009) (Fig. 1). However, Clerc (2004) stated that between 700 to 800 taxon names were actually published under the genusalthough a reliable approximation is not entirely clear yet. This scenario supports the fact that Usnea is often regarded as taxonomically difficult by lichenologists and hence needs to be revised (Clerc 1998). Despite the lack of published materials, most studies on the genus make use of morphological and biochemical approaches in the identification of specimens up to the species level. This approach on Usnea can be extremely difficult due to the existence of some specimens that may look distinct from one another but are actually the same at the species level. Articus (2004) recognized this situation and stated that some species of Usnea are "extremely variable and ecophenotypes of the same species may look radically different".

Having thalli that can grow up to several feet, the longest lichen species ever recorded is under this genus (Usnea longissima). Likewise, few Usnea species also have distinguishing characteristics. For example, Usnea ceratina has coarse thalli and pink medulla (Fig. 2). In the Philippines, about 32 species of Usnea have been reported (Bawingan et al. 2000, Santiago et al. 2010, Galinato et al. 2017). However, this number is inconsistent because there are existing reports on other species of Usnea in the country that are not properly accounted in literature. 


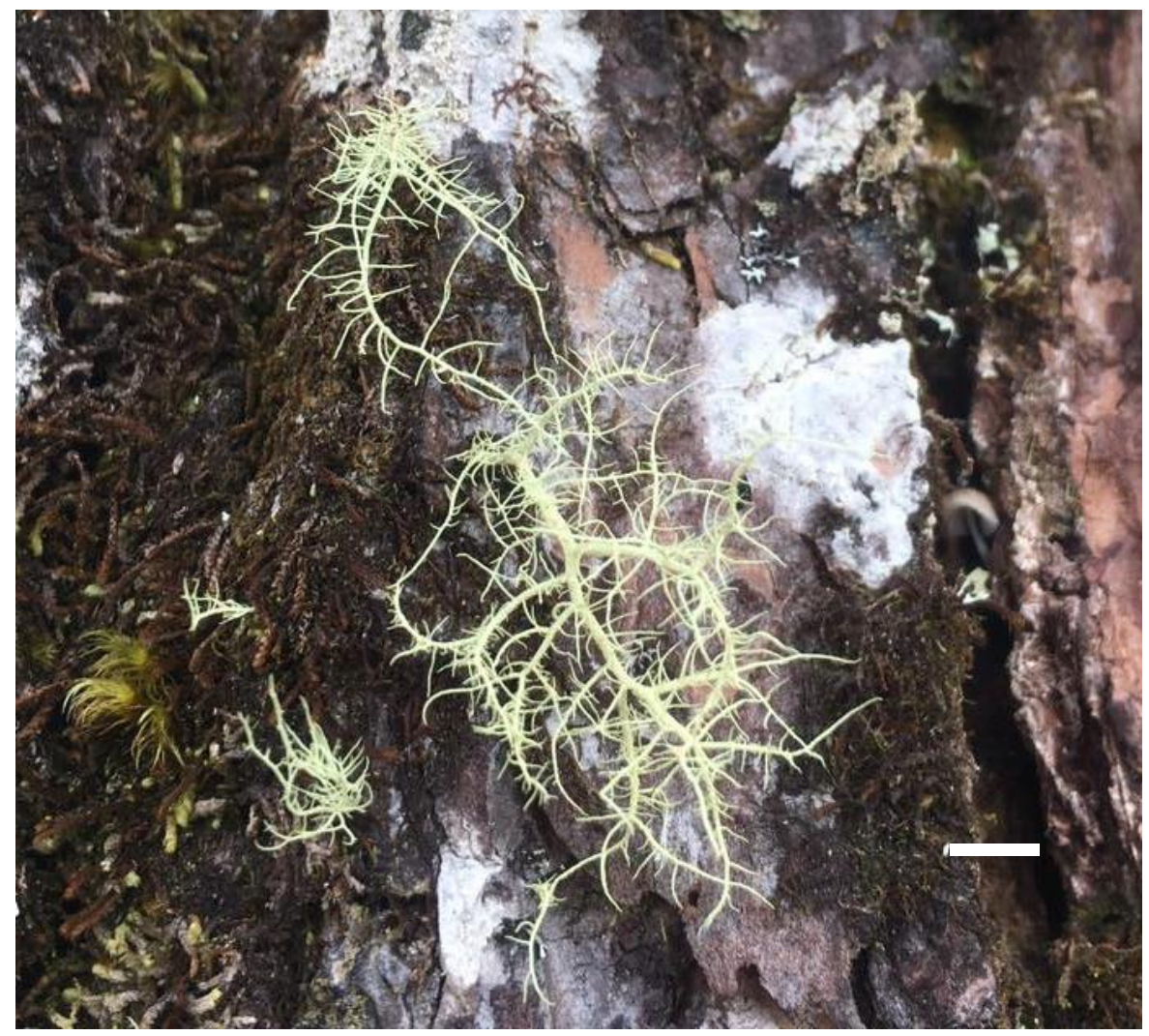

Fig. 1 - An epiphytic Usnea in Mt. Amuyao in Mountain Province, Philippines. Scale bar $=2 \mathrm{~cm}$.
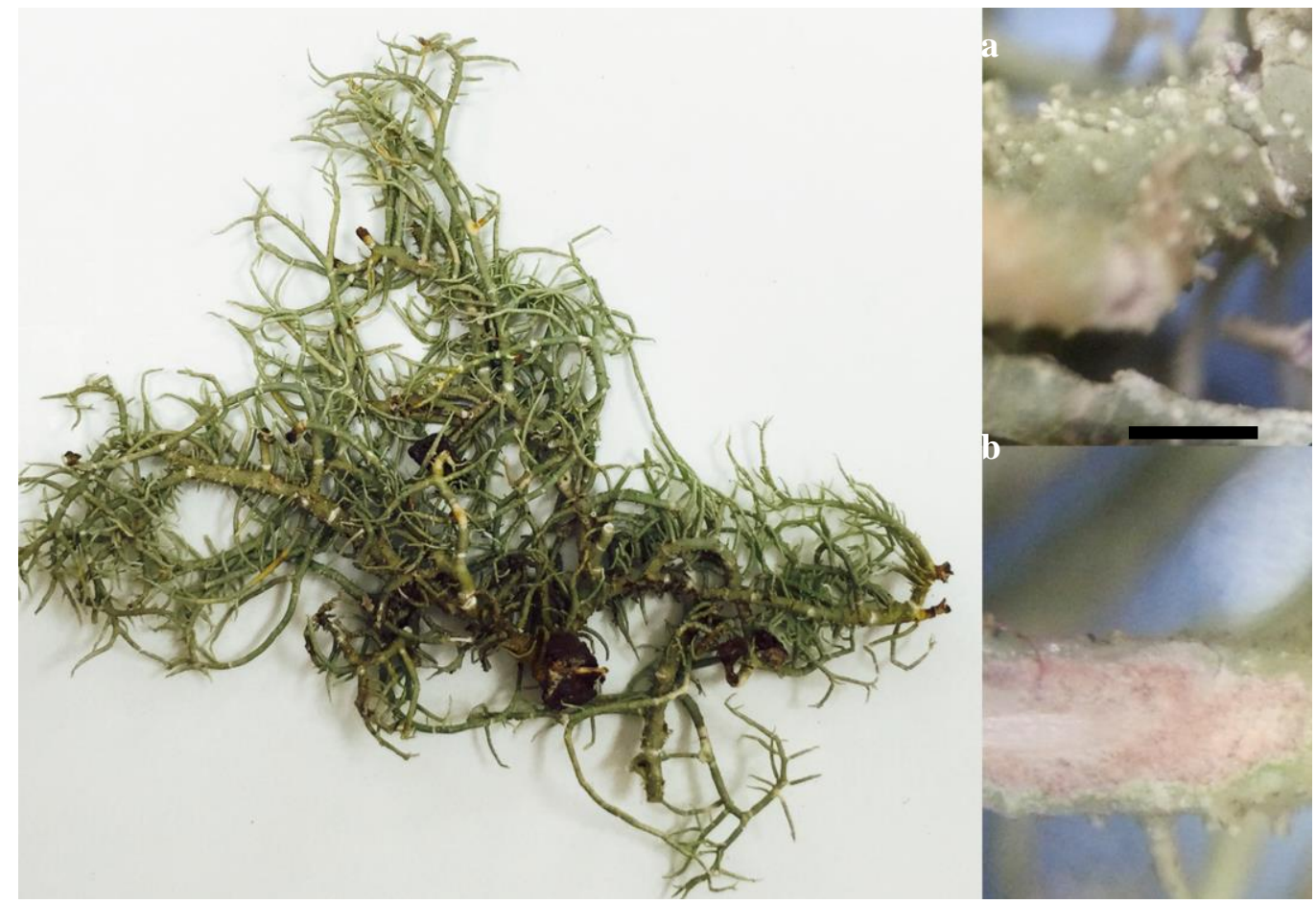

Fig. 2 - U. ceratina with its (a) coarse thallus and (b) the pink medulla. Scale bar $=1 \mathrm{~mm}$.

Vainio's preliminary work on Philippine lichens reported 10 species of Usnea in Luzon Island (Vainio 1909), in which the longest lichen, U. longissima, and the species named after the country, U. philippina, were reported. After 28 years, Motyka (1937) continued to explore the country and was able to name a new species believed to have been discovered first in Misamis Occidental, Northern Mindanao (U. misamisensis). Meanwhile, Quisumbing (1951) was the first to 
report the medicinal use of Philippine Usnea which can cure stomach pain according to his book, "Medicinal Plants of the Philippines" (dela Cruz et al. 2013). A similar study also claimed the pharmacological use of U. barbata in Iloilo as a treatment for wounds (Madulid et al. 1989). This paper is so far the only known paper that reports the presence of the genus in the Visayas region.

Moreover, dela Cruz et al. (2013) recognized the work of Herre (1963) as the most extensive enumeration of Usnea spp. in the country. The study listed 25 species of Usnea for the entire Philippines. Presently, there are online catalogues that record the early studies of Sevilla-Santos (1965, 1979) and Sevilla-Santos \& Mondragon (1972) on Usnea. Sevilla-Santos' work in 1965 focused on the antimicrobial activities of U. montagnei and its antibiotic constituents. Following this was the study of several lichens and their thin-layer chromatographic profiles by Sevilla-Santos \& Mondragon (1972). This included five species of Usnea. Sevilla-Santos' work in 1979 is his most credited one, which finally classified the locally-known "lumot niyog" as the lichen Usnea. In 2000, Bawingan et al. carried out an extensive research on the lichen flora of the Cordillera which recorded three Usnea spp. in Benguet. The book of Stevens (2004) reported the occurrence of some Usnea spp. in Laguna and Lanao del Norte, one of which was a new record for the Philippines at that time (U. himantodes).

Recent applications of Usnea were studied by Santiago et al. (2010, 2013) who, collectively, demonstrated the antibacterial activities and secondary metabolic profiles of fruticose lichens and 27 Usnea spp., respectively. These studies were credited by many lichenologists all over the world and were used as primary references in studying the genus' taxonomy and secondary metabolic applications (Kosanić \& Ranković 2015, Shukla 2015, Galinato et al. 2017, Timbreza et al. 2017). The same paper also added 14 new records of Usnea for the country, namely: $U$. articulata, $U$. baileyi, $U$. ceratina, $U$. chaetophora, $U$. cornuta, $U$. fragilescens, $U$. glabrata, $U$. haumanii, $U$. hesperina (syn. U. subgracilis), $U$. hirta, $U$. intermedia, $U$. nidulans, $U$. sorediosula, and U. subcornuta. Furthermore, Sipman et al. (2013) produced a catalogue of 162 lichen species in Palawan which included three Usnea spp. A recent antibacterial study by Timbreza et al. (2017) reported 36 species of Usnea from Bukidnon. Interestingly, 21 of these species are new records for the country, namely: U. aciculifera, U. amabilis, U. bismolliuscula, $U$. filipendula, $U$. fragilescens var. mollis, $U$. grandisora, $U$. hakonensis, $U$. himalayana, $U$. nipparensis, U. orientalis, U. pangiana, U. poliotrix, U. praetervisa, U. pygmoidea, U. scabrata, $U$. sphacelata, U. subdaseae, U. subfloridana, U. subrubricornuta, U. transitoria, and U. wasmuthii. This paper is, by far, the one that contributed most in the addition of new records of Usnea for the Philippines. The most recent paper focusing on Philippine Usnea was by Galinato et al. (2017) which determined the diversity of the genus in each municipality of the province of Kalinga. According to the study, a total of 25 species were reported in the province including seven new records for the country, namely: U. cavernosa, U. dasaea, U. dasypoga, U. flavocardia, $U$. glabrescens, $U$. lapponica, and $U$. silesiaca.

This paper serves as a checklist of all the reported species of Usnea in the Philippines and highlights the provinces where Usnea spp. have already been reported in. Additionally, this collectively summarizes all the studies conducted on Philippine Usnea and updates the national record. All species have been initially verified through suggested online mycological databases such as MycoBank (International Mycological Association, United Kingdom) and Index Fungorum (Royal Botanic Gardens Kew, United Kingdom) to sort out the synonymy. Since there was a recent increase in the number of new records for the country, it is vital to establish an accurate count of species for future studies. The paper can also serve as a reference to track a species, mainly if intended for a study (e.g., allelopathy, bioactivities, biomonitoring, phylogeny, etc.).

\section{Discussion}

Despite the recent progress on lichenological studies in the country, there is barely fundamental research on Philippine Usnea. The taxonomic challenge of the genus is the main contributing factor to this. This led to the lack of published materials focusing on the nature, ecology, and systematics of the genus. Still, it is not surprising that this fruticose lichen is diversely 
found in the higher portions of the Philippine forests. This claim is evident in the studies of Herre (1963), Santiago et al. (2013), Timbreza et al. (2017), Galinato et al. (2017), wherein a copious number of specimens were collected individually per study. To date, there is only one known paper that reports the occurrence of Usnea in the Visayan Islands which, particularly, describes the ethnopharmacological use of $U$. barbata in Iloilo (Madulid et al. 1989) (Fig. 3). Species of another fruticose lichen, Ramalina, is reported in some parts of the Visayan region. Hence, it is not impossible that Usnea can also be found in most parts of Visayas. It is worth noting, though, that Ramalina spp. are more capable of growing in lower elevations ( 400 masl) than Usnea ( 600 masl and above) as observed during fieldworks. In addition to this, the two genera do not often coexist in the field. Ramalina is usually associated with foliose lichens in lower areas whereas Usnea is frequently observed inhabiting the same tree as Cladonia in higher elevations. Therefore, the occurrence of Usnea in a particular site might also be influenced by the elevation.

Many of the existing studies did not specifically mention where the Usnea specimens were collected in the country (Quisumbing 1951, Herre 1963, Sevilla-Santos 1965, Sevilla-Santos \& Mondragon 1972, Sevilla-Santos 1979). This posed many problems when preparing an accurate map for the localities of Usnea all over the Philippines (Fig. 3). According to Mycobank and Index Fungorum, many species of Usnea had synonymized. This was taken into account alongside papers focusing on the revision of the genus. The names that were discovered synonyms of another taxon (e.g., Usnea arida $=U$. rubrotincta) were collectively considered as only one count of species and the current accepted name is used in this review. For instance, it was proposed by Truong et al. (2013) that the synonymy of $U$. hesperina with $U$. schadenbergiana be rejected and instead $U$. hesperina be reclassified as U. subgracilis. In the paper of Sevilla-Santos \& Mondragon (1972), $U$. intercalaris was one of the species reported. Its current accepted name was changed to $U$. nidifica and was used by Timbreza et al. (2017) in their paper. Thus, U. nidifica is registered under both studies in this paper. Meanwhile, U. hossei, U. misamisensis, and U. pectinata were all reclassified as Eumitria pectinata by Articus (2004). Eumitria was a subgenus of Usnea alongside two other subgenera until molecular works gave Eumitria the generic rank (Articus 2004). However, other authors agreed to keep Eumitria as a subgenus "since the backbone of the phylogeny of Usnea s. lat. remained unresolved and phenotypic characters used to circumscribe the lineages were ambiguous" (Truong \& Clerc 2013). Eumitria pectinata is currently the accepted name in Index Fungorum despite of this debate but is still considered under Usnea in this review paper (Table 1).

Table 1 Reclassified names of some Usnea spp. in the Philippines

\begin{tabular}{|c|c|c|}
\hline Current accepted name & Previous name(s) used in literature & Author \\
\hline \multirow{3}{*}{ E. pectinata ${ }^{\mathrm{a}}$} & U. hossei ${ }^{\mathrm{b}}$ & \multirow{5}{*}{$\begin{array}{l}{ }^{\mathrm{d}} \text { Taylor (1847) } \\
\text { e'Krempelhuber (1874) } \\
\text { fVainio (1915) } \\
{ }^{\text {b} V a i n i o ~(1921) ~} \\
\text { cMotyka (1937) } \\
{ }^{\mathrm{a}} \text { Articus (2004) }\end{array}$} \\
\hline & U. misamisensis ${ }^{\mathrm{c}}$ & \\
\hline & U. pectinata ${ }^{\mathrm{d}}$ & \\
\hline U. nidifica ${ }^{\mathrm{d}}$ & U. intercalaris ${ }^{\mathrm{e}}$ & \\
\hline U. subgracilis $^{\mathrm{f}}$ & U. hesperina ${ }^{\mathrm{c}}$ & \\
\hline
\end{tabular}

In lieu of these taxonomic changes, this paper used the reclassified taxon names of Usnea spp. that are accepted by the said mycological databases. A total of 81 taxa have been determined for the country from the $19^{\text {th }}$ century up to date. This number includes the previously-named $U$. hossei, U. misamisensis and U. pectinata, which are now all under the name Eumitria pectinata (although this is still debatable). Therefore, based on literature, 81 species are found in the Philippines following the pronounced contributions by recent studies (Table 2). This number, though, is only a mere estimate since revisions are unavoidable in taxonomic classification.

The great increase in number of recorded species in the Philippines may be due to the extensive identification keys and taxonomic studies that became available worldwide (Halonen et al. 1998, Goward et al. 1994, Halonen 2000, McCune 2005, Randlane et al. 2009, Ohmura 2008, 2012, 2014, Ohmura et al. 2010, Truong et al. 2011, Shukla et al. 2014) long after the study on 
Usnea began in the country. These keys provided better distinction of the specimens that earlier studies may have failed to do which resulted to the clustering of some morphospecies. Chemotaxonomic and molecular methods now also strongly supplement morphological and biochemical data and thus enable a more accurate characterization and identification within the lichen genus.

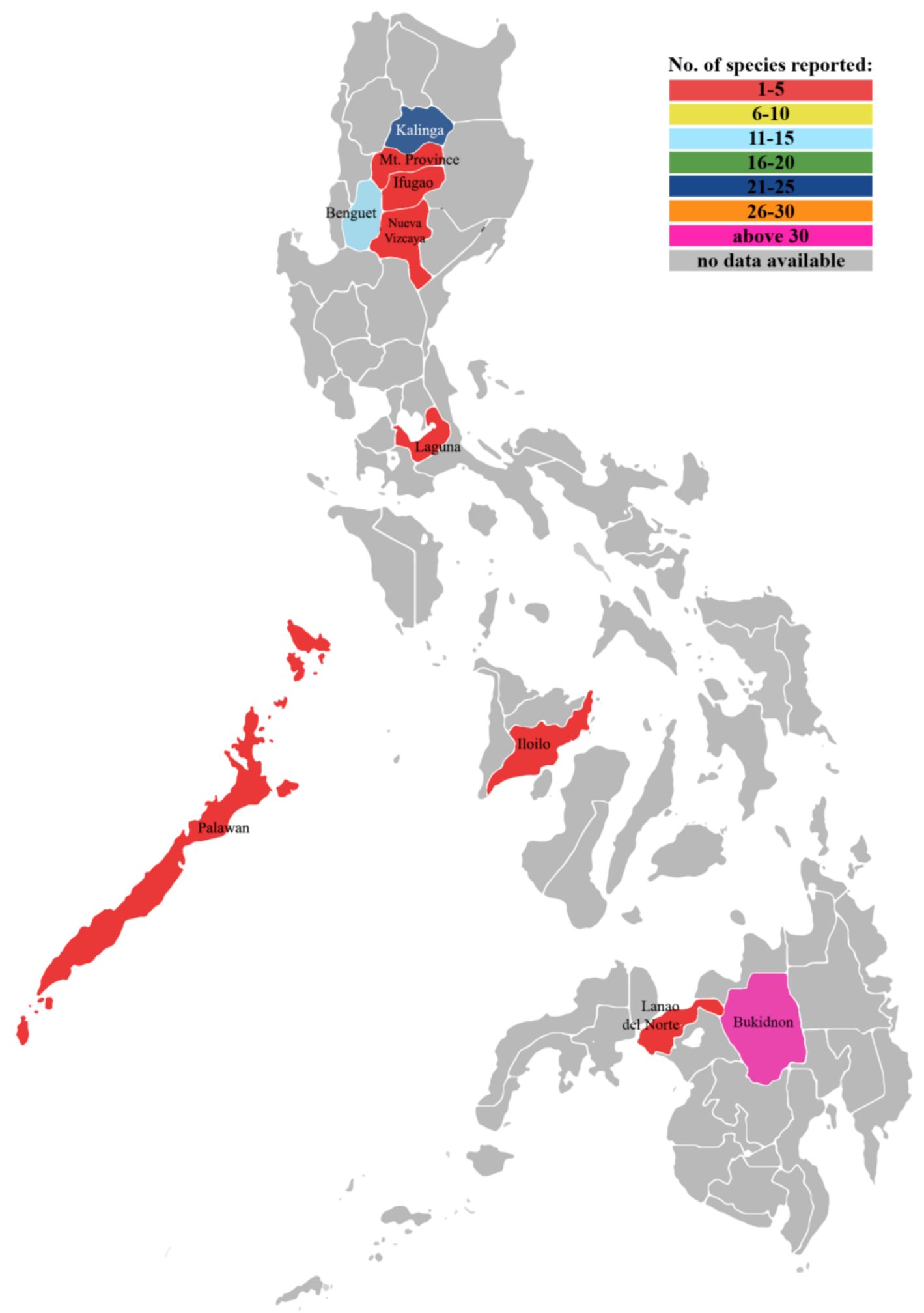

Fig. 3 - Provinces in the Philippines reported with Usnea based on literature. Vector map obtained from Wikipedia Commons. 
Table 2 Enumeration of Usnea spp. reported in the country and their localities

\begin{tabular}{|c|c|c|}
\hline Species & Reported location(s) & References \\
\hline U. australis & Luzon Island & Vainio (1909) \\
\hline U. aciculifera & Bukidnon & Timbreza et al. (2017) \\
\hline U. amabilis & Bukidnon & Timbreza et al. (2017) \\
\hline U. articulata & Ifugao, Kalinga, Mountain Province & Santiago et al. (2013), Galinato et al. (2017) \\
\hline U. baileyi & $\begin{array}{l}\text { Benguet, Bukidnon, Ifugao, Kalinga, } \\
\text { Palawan }\end{array}$ & $\begin{array}{l}\text { Santiago et al. (2010; 2013), Sipman et al. } \\
\text { (2013), Timbreza et al. (2017), Galinato et } \\
\text { al. (2017) }\end{array}$ \\
\hline U. barbata & Bukidnon, Iloilo, Kalinga & $\begin{array}{l}\text { Madulid et al. (1989), Timbreza et al. } \\
\text { (2017), Galinato et al. (2017) }\end{array}$ \\
\hline U. bismolliuscula & Bukidnon & Timbreza et al. (2017) \\
\hline U. cavernosa & Kalinga & Galinato et al. (2017) \\
\hline U. ceratina & Benguet, Bukidnon, Kalinga & $\begin{array}{l}\text { Santiago et al. (2013), Timbreza et al. } \\
\text { (2017), Galinato et al. (2017) }\end{array}$ \\
\hline U. chaetophora & Bukidnon, Ifugao, Kalinga & $\begin{array}{l}\text { Santiago et al. (2013), Timbreza et al. } \\
\text { (2017), Galinato et al. (2017) }\end{array}$ \\
\hline U. chrysopoda & Unknown & Herre (1963) \\
\hline U. ciliata & Luzon Island & Vainio (1909) \\
\hline U. cornuta & Benguet, Bukidnon, Ifugao, Kalinga & $\begin{array}{l}\text { Santiago et al. (2013), Timbreza et al. } \\
\text { (2017), Galinato et al. (2017) }\end{array}$ \\
\hline U. dasaea & Kalinga & Galinato et al. (2017) \\
\hline U. dasypoga & Kalinga & Galinato et al. (2017) \\
\hline U. dimorpha & Benguet & Bawingan et al. (2000) \\
\hline U. diplotypus & Bukidnon, Kalinga & Timbreza et al. (2017), Galinato et al. (2017) \\
\hline U. elmeri & Unknown & $\begin{array}{l}\text { Herre (1963), Sevilla-Santos \& Mondragon } \\
\text { (1972) }\end{array}$ \\
\hline U. erecta & Unknown & Herre $(1963)$ \\
\hline U. esperantiana & Bukidnon, Kalinga & Timbreza et al. (2017), Galinato et al. (2017) \\
\hline U. eumitroides & Unknown & Herre $(1963)$ \\
\hline U. filipendula & Bukidnon & Timbreza et al. (2017) \\
\hline U. flammea & Bukidnon, Kalinga & Timbreza et al. (2017), Galinato et al. (2017) \\
\hline U. flavocardia & Kalinga & Galinato et al. (2017) \\
\hline U. flexilis & Palawan & $\begin{array}{l}\text { Herre (1963), Sevilla-Santos \& Mondragon } \\
\text { (1972), Sipman et al. (2013) }\end{array}$ \\
\hline U. florida & Luzon Island & Vainio (1909) \\
\hline U. fragilescens & $\begin{array}{l}\text { Benguet, Bukidnon, Cavite, Ifugao, } \\
\text { Kalinga, Nueva Ecija }\end{array}$ & $\begin{array}{l}\text { Santiago et al. (2013), Timbreza et al. } \\
\text { (2017), Galinato et al. (2017) }\end{array}$ \\
\hline U. fragilescens var. mollis & Bukidnon & Timbreza et al. (2017) \\
\hline U. furcata & Luzon Island & Vainio $(1909)$ \\
\hline U. glabrata & Benguet, Bukidnon, Ifugao, Kalinga & $\begin{array}{l}\text { Santiago et al. (2013), Timbreza et al. } \\
\text { (2017), Galinato et al. (2017) }\end{array}$ \\
\hline U. glabrescens & Kalinga & Galinato et al. (2017) \\
\hline U. grandisora & Bukidnon & Timbreza et al. (2017) \\
\hline U. hakonensis & Bukidnon & Timbreza et al. (2017) \\
\hline U. haumanii & Ifugao & Santiago et al. (2013) \\
\hline U. himalayana & Bukidnon & Timbreza et al. (2017) \\
\hline U. himantodes & Luzon Island & Stevens (2004) \\
\hline
\end{tabular}


Table 2 Continued.

\begin{tabular}{|c|c|c|}
\hline Species & Reported location(s) & References \\
\hline U. hirta & Benguet, Ifugao, Kalinga & Santiago et al. (2013), Galinato et al. (2017) \\
\hline U. humulis & Unknown & Herre (1963) \\
\hline U. implicata & Unknown & Herre (1963) \\
\hline U. insignis & Unknown & Herre (1963) \\
\hline U. intermedia & Ifugao & Santiago et al. (2013) \\
\hline U. lapponica & Kalinga & Galinato et al. (2017) \\
\hline U. laevata & Unknown & Herre (1963) \\
\hline U. longgisma & Kalinga, Luzon Island & $\begin{array}{l}\text { Vainio (1909), Herre (1963), Galinato et al. } \\
\text { (2017) }\end{array}$ \\
\hline U. marivelensis & Unknown & Herre (1963) \\
\hline U. mearnsii & Unknown & Herre (1963) \\
\hline U. montagnei & Unknown & Herre (1963), Sevilla-Santos $(1965 ; 1979)$ \\
\hline U. nidifica & Bukidnon & $\begin{array}{l}\text { Sevilla-Santos \& Mondragon (1972), } \\
\text { Timbreza et al. (2017) }\end{array}$ \\
\hline U. nidulans & Ifugao, Kalinga & Santiago et al. (2013), Galinato et al. (2017) \\
\hline U. nipparensis & Bukidnon & Timbreza et al. (2017) \\
\hline U. orientalis & Bukidnon & Timbreza et al. (2017) \\
\hline U.pangiana & Bukidnon & Timbreza et al. (2017) \\
\hline U.perplexans & Luzon Island & Vainio (1909) \\
\hline U.philippina & Luzon Island, Masbate & $\begin{array}{l}\text { Vainio (1909), Quisumbing (1951), Herre } \\
\text { (1963), NDIC }\end{array}$ \\
\hline U. poliotrix & Bukidnon & Timbreza et al. (2017) \\
\hline U. praetervisa & Bukidnon & Timbreza et al. (2017) \\
\hline U. pycnoclada & Laguna & Vainio (1909), Herre (1963), Stevens (2004) \\
\hline U.pygmoidea & Bukidnon & Timbreza et al. (2017) \\
\hline U. ramosii & Unknown & Herre (1963) \\
\hline U. roseola & Unknown & Herre (1963) \\
\hline U. rubrotincta & Unknown & Herre (1963), Timbreza et al. (2017) \\
\hline U. rubicunda & $\begin{array}{l}\text { Benguet, Bukidnon, Ifugao, Kalinga, } \\
\text { Nueva Vizcaya }\end{array}$ & $\begin{array}{l}\text { Herre (1963), Bawingan et al. (2000), } \\
\text { Santiago et al. (2013), Timbreza et al. } \\
\text { (2017), Galinato et al. (2017) }\end{array}$ \\
\hline U. rubicunda var. rosea & Unknown & Herre (1963) \\
\hline U. scabrata & Bukidnon & Timbreza et al. (2017) \\
\hline U. schadenbergiana & Ifugao, Kalinga & $\begin{array}{l}\text { Herre (1963), Santiago et al. (2013), } \\
\text { Galinato et al. (2017) }\end{array}$ \\
\hline U. silesiaca & Kalinga & Galinato et al. (2017) \\
\hline U. sorediosula & Mountain Province & Santiago et al. (2013) \\
\hline U. sphacelata & Bukidnon & Timbreza et al. (2017) \\
\hline U. squarrosa & Luzon Island, Lanao del Norte & $\begin{array}{l}\text { Vainio (1909), Herre (1963), Sevilla-Santos } \\
\text { \& Mondragon (1972) }\end{array}$ \\
\hline U. subcornuta & Benguet, Ifugao & Santiago et al. (2013) \\
\hline U. subdasaea & Bukidnon & Timbreza et al. (2017) \\
\hline U. subfloridana & Bukidnon & Timbreza et al. (2017) \\
\hline U. subgracilis & Benguet, Ifugao, Nueva Vizcaya & Santiago et al. (2013) \\
\hline U. subrubricornuta & Bukidnon & Timbreza et al. (2017) \\
\hline
\end{tabular}


Table 2 Continued.

\begin{tabular}{lll}
\hline Species & Reported location(s) & References \\
\hline $\boldsymbol{U}$. subscabrosa & Benguet, Ifugao, Kalinga & $\begin{array}{l}\text { Bawingan et al. (2000), Santiago et al. } \\
(2013), \text { Galinato et al. (2017) }\end{array}$ \\
\hline $\boldsymbol{U}$. substerilis & Bukidnon, Kalinga & Timbreza et al. (2017), Galinato et al. (2017) \\
\hline $\boldsymbol{U}$. transitoria & Bukidnon & Timbreza et al. (2017) \\
\hline $\boldsymbol{U}$. trichodea & Luzon Island & Vainio (1909) \\
\hline $\boldsymbol{U}$ wasmuthii & Bukidnon & Timbreza et al. (2017) \\
\hline Eumitria pectinata & Bukidnon, Luzon Island & $\begin{array}{l}\text { Motyka (1937), Herre (1963), Sipman et al. } \\
\text { (2013), Timbreza et al. (2017) }\end{array}$ \\
\hline
\end{tabular}

The number of Usnea species reported in the country is a proof that Philippines indeed harbor a diverse flora and fauna. The big shift in number of reported species in the country (from 32 to 81) supports the fact that Usnea and lichens, in general, are certainly understudied locally. As more places in the country remain unexplored, the more lichens are yet to be discovered. This paper may have established a new piece of information in Philippine Lichenology but it also opened a lot of questions that, hopefully, future studies may answer. It is therefore imperative to keep the series of lichenological studies on-going.

\section{Acknowledgements}

The authors are indebted to Dr. Arvin C. Diesmos and Dr. Cecilia I. Banag for inspiring the production of this paper and their contributions to Philippine Biodiversity and Systematic studies. This paper is especially dedicated to Prof. Dr. Thomas Edison E. dela Cruz who is a mentor to the authors. His contribution to the Fungal Diversity and Systematic studies in the Philippines is recognized.

\section{References}

Articus K. 2004 - Phylogenetic studies in Usnea (Parmeliaceae) and allied genera. Comprehensive summaries of uppsala dissertations from the faculty of science and technology. Acta universitatis upsaliensis, 1-29.

Bawingan PA, Flores YG, Lardizabal MP, Rosuman PF. 2000 - Flora of the Cordillera (I): BaguioBenguet Lichens. Baguio: Saint Louis University-National Research Unit.

Clerc P. 1998 - Species concepts in the genus Usnea (Lichenized Ascomycetes) - The Lichenologist 30, 321-340.

Clerc P. 2004 - Notes on the genus Usnea Adanson. II. Bibliotheca Lichenologica 88, 79-90.

dela Cruz TEE, Dagamac NHA, Torres JMO, Santiago KAA, Yulo PRJ. 2013 - Review of Mycology in the Philippines. Philippine Academy of Microbiology Proceedings 2013, 61-68. Retrieved from https://www.researchgate.net/publication/283318357 (accessed 14 December 2017).

Galinato MGM, Mangubat CB, Leonor DS, Cababa GRC, Cipriano BPS, Santiago KAA. 2017 Identification and diversity of the fruticose lichen Usnea in Kalinga, Luzon Island, Philippines. Current Research in Environmental \& Applied Mycology 7(4), 249-257.

Goward T, McCune B, Meidinger D. 1994 - The lichens of British Columbia, illustrated keys: Part 1, Foliose and squamulose species. British Columbia Ministry of Forests Research Program.

Halonen P, Clerc P, Goward T, Brodo IM, Wulff K. 1998 - Synopsis of the genus Usnea (Lichenized Ascomycetes) in British Columbia, Canada. Bryologist 101, 36-60.

Halonen P. 2000 - Studies on the lichen genus Usnea in East Fennoscandia and Pacific North America. Academic Dissertation. Faculty of Science, University of Oulu, Finland.

Hawksworth DL, Kirk PM, Sutton BC, Pegler DN. 1995 - Ainsworth \& Bisby's Dictionary of the Fungi 8th ed. CAB International, Wallingford. 
Herre A. 1963 - The lichen genus Usnea and its species at present known from the Philippines. Philippine Journal of Science 92(1), 41-76.

Kosanić M, Ranković B. 2015 - Lichen secondary metabolites as potential antibiotic agents. In: B. Rankovic' (ed.), Lichen Secondary Metabolites: bioactive properties and pharmaceutical potential. Springer International Publishing Switzerland, 81-104.

Krempelhuber A. 1874 - Lichenes Brasilienses. Partic. XIV von E. Warming, Symbolae ad floram Brasiliae cognoscendum. Videnskab. Meddel. naturhist. Forening Kjöbenhavn 5, 1-35.

Madulid DA, Gaerlan FJM, Romero EM, Agoo EMG. 1989 - Ethnopharmacological study of the Ati tribe in Nagpana, Barotac Viejo, Iloilo. Acta Manilana 38, 25-40.

McCune B. $2005-$ Usnea in the Pacific Northwest. Retrieved from http://oregonstate.edu/ mccuneb/Usnea.pdf (accessed 12 December 2017).

Motyka J. 1937 - Lichenum Generis Usnea Studium Monographicum. Pars Systematica 2, 305560.

Ohmura Y. 2008 - Taxonomy and molecular phylogeny of Usnea rubicunda and U. rubrotincta (Parmeliaceae, lichenized Ascomycotina). Journal of Japanese Botany 83, 347-355.

Ohmura Y, Lin CK, Wang PH. 2010 - Three sorediate species of the genus Usnea (Parmeliaceae, Ascomycota) new to Taiwan. Memoirs of the National Science Museum 46, 69-76.

Ohmura Y. 2012 - A synopsis of the lichen genus Usnea (Parmeliaceae, Ascomycota) in Taiwan. Memoirs of the National Museum of Nature and Science 48, 91-137.

Ohmura Y. 2014 - Usnea flavocardia (Parmeliaceae, lichenized Ascomycota) New to Asia. Bull. Natl. Mus. Nat. Sci. 40, 69-72.

Quisumbing E. 1951 - Medicinal plants of the Philippines. Bureau of Printing, Manila, Philippines.

Randlane T, Torra T, Saag A, Saag L. 2009 - Key to European Usnea species. Bibliotheca Lichenologica 100, 419-462.

Santiago KAA, Borricano JN, Canal JN, Marcelo DMA, Perez MCP, dela Cruz TEE. 2010 Antibacterial activities of fruticose lichens collected from selected sites in Luzon Island, Philippines. Philippine Science Letters 2, 18-28.

Santiago KAA, Sangvichien E, Boonpragob K, dela Cruz TEE. 2013 - Secondary metabolic profiling and antibacterial activities of different species of Usnea collected in Northern Philippines. Mycosphere 4, 267-280.

Sevilla-Santos P. 1965 - Antibiotic constituents of a Philippine lichen, Usnea sp. Academic dissertation. University of the Philippines Diliman, Quezon city, Philippines.

Sevilla-Santos P, Mondragon AM. 1972 - Studies on Philippine lichens, II. Thin-layer chromatographic study of the constituents of some lichen species. Philippine Journal of Science 98, 297-302.

Sevilla-Santos P. 1979 - Philippine Lichens 3 1. Identification and classification of lumot niyog as Usnea montagnei. Acta Manilana, 67-76.

Shukla P, Upreti DK, Tewari LM. 2014 - Lichen genus Usnea (Parmeliaceae, Ascomycota) in Uttarakhand, India. Current Research in Environmental \& Applied Mycology 4(2), 188-201.

Shukla P, Upreti DK, Tewari LM. 2015 - Secondary metabolite variability in lichen genus Usnea in India: A potential source for bioprospection. G-Journal of Environmental Science and Technology 3, 29-40.

Sipman HJM, Diederich P, Aptroot A. 2013 - New lichen records and a catalogue of lichens from Palawan Island, The Philippines. Philippine Journal of Science 142, 199-2010.

Stevens GN. 2004 - Usneaceae. In: McCarthy PM, Mallett K (eds), Flora of Australia Vol. 56A, Lichens 4. Melbourne ABRS/CSIRO, 107-115.

Taylor T. 1847 - New lichens, principally from the Herbarium of Sir William J. Hooker. London Journal of Botany 6, 148-197

Timbreza LP, Delos Reyes JL, Flores CH, Perez RJLA, Stockel MAS, Santiago KAA. 2017 Antibacterial activities of the lichen Ramalina and Usnea collected from Mt. Banoi, Batangas and Dahilayan, Bukidnon, against multi-drug resistant (MDR) bacteria. Austrian Journal of Mycology 26, 27-42. 
Truong C, Bungartz F, Clerc P. 2011 - The lichen genus Usnea (Parmeliaceae) in the tropical Andes and the Galapagos: species with a red-orange cortical or subcortical pigmentation. Bryologist 114.

Truong C, Clerc P. 2013 - Eumitrioid Usnea species (Parmeliaceae, lichenized Ascomycota) in tropical South America and the Galapagos. The Lichenologist 45(3), 383-395.

Vainio EA. 1909 - Étudesur la classification naturelleet la morphologie des lichens du Brésil. Acta Societatis pro Fauna et Flora Fennica. Helsinki (Finland): Héritiers J. Simelius.

Vainio EA. 1915 - Additamenta ad lichenographiam Antillarum illustrandum. Annales Academiae Scientiarum Fennicae 6(7), 1-226.

Vainio EA. 1921 - Lichenes ab A. Yasuda in Japonia collecti. Continuatio I. Botanical Magazine Tokyo 35, 45-79. 